\title{
Larval stages of two deep sea pycnogonids
}

\author{
John A. Fornshell \\ Department of Invertebrate Zoology, National Museum of Natural History, Smithsonian Institution, \\ Washington DC, USA \\ E-mail: johnfornshell@hotmail.com
}

ABSTRACT. The larvae of two species of sea spiders in the archived collections of the Smithsonian Institution's National Museum of Natural History (NMNH) are described: the first three instars of Ammothea allopodes Fry et Hedgpeth 1969, and one late post-hatching stage of Nymphon tenellum (Sars, 1888). Ammothea allopodes larval stages are examples of a typical protonymphon larva. The single stage of $N$. tenellum does not fit into any of the five recognized larval developmental patterns; it displays characteristics of an attaching larva, an encysting larva and a typical protonymphon larva. These characteristics are: (1) 3-segmented larval appendages I, II and III; (2) underived buds of appendages IV-VI, walking legs 1, 2 and 3, present; (3) the digestive tract is incomplete, there is no proctodeum present; and (4) a large amount of yolk is present. A new developmental pattern is proposed for this larval stage.

How to cite this article: Fornshell J.A.. 2015. Larval stages of two deep sea pycnogonids // Invertebratze Zoology. Vol.12. No.2. P.197-205. doi: 10.15298/invertzool.12.2.05

KEY WORDS: Pycnogonida, protonymphon larva, larval stages.

\section{Личиночные стадии двух глубоководных пикногонид}

\section{Джон А. Форншелл}

РЕЗЮМЕ. По материалам коллекций Национального музея естественной истории Смитсоновского института описаны личиночные стадии двух видов морских пауков: первые три личиночных стадии Ammothea allopodes Fry et Hedgpeth 1969, и одна поздняя личиночная стадия Nymphon tenellum (Sars, 1888). Личинки Ammothea allopodes представляют собой типичных протонимфонов. Строение исследованной личиночной стадии $N$. tenellum не укладывается ни в один из пяти известных планов личиночного развития пикногонид; оно включает черты прикрепляющейся личинки, инцистирующейся личинки и типичного протонимфона. Эта личинка имеет: (1) 3сегментные личиночные конечности I, II и III; (2) не развитые зачатки конечностей IV-VI, и ходильных ног 1, 2 и 3; (3) пищеварительный тракт без задней кишки; (4) большое количество запасенного желтка. Предлагается новый план развития для этой личинки.

Как цитировать эту статью: Fornshell J.A. 2015. Larval stages of two deep sea pycnogonids // Invertebratze Zoology. Vol.12. No.2. P.197-205. doi: 10.15298/invertzool.12.2.05

КЛЮЧЕВЫЕ СЛОВА: Рycnogonida, личинка протонимфон, личиночные стадии. 


\section{Introduction}

Pycnogonida, sea spiders, have an unusual reproductive strategy for Arthropods, the males care for the eggs and early postembryonic developmental stages. When sexually competent adults encounter members of the opposite sex, the female crawls over the male and releases her eggs into the water. At the same time the male releases his sperm into the water and fertilization occurs externally. After mating, the male collects and carries the eggs on modified third legs called ovigerous appendages. When the eggs hatch and, depending on the developmental pattern of the species, the male may continue to carry the developing larvae until they reach a stage resembling the adults (King, 1973; Bain, 2003). In this study the larvae of two species of sea spiders in the archived collections of the National Museum of Natural History (NMNH) are described. Ammothea allopodes Fry et Hedgpeth, 1969 is represented by its first three post embryonic instars among specimens collected from the Antarctic Ocean. The second species, Nymphon tenellum (Sars, 1888), is described from specimens collected from the North Atlantic Ocean. Only one stage of this latter species was present in the collections. About $5 \%$ of the larvae of the 1300+ known species of the Pycnogonida have been described to date. The objective of this study is to add descriptions of larvae from adult males of two species archived in the National Museum of Natural History.

\section{Methods}

A protonymphon larva of $A$. allopodes (NMNH 1122814), and the second and third larval stages were removed from an ovigerous male specimen collected from the Antarctic Ocean on 15 March 1964 at $62.7^{\circ} \mathrm{S}, 54.7^{\circ} \mathrm{W}$ at a depth of $265 \mathrm{~m}$ by researchers on the $\mathrm{R} / \mathrm{V}$ ELTANIN. Eggs and a single larval stage of $N$. tenellum (NMNH 181089) were collected from the North Atlantic Ocean on 22 February 1969 at $39^{\circ} 47.36^{\prime} \mathrm{N}, 70^{\circ} 49.54^{\prime} \mathrm{W}$ at a depth $1501-$ $1693 \mathrm{~m}$ by the R/V CHAIN. At the time of collection, all specimens were fixed in a formal- dehyde solution and, after species determination at the Natural History Museum, stored in a $70 \%$ ethyl alcohol solution. This method of preservation is not the best for making electron microscope images, in that the specimens are often partially dehydrated and appear wrinkled.

For this study, larvae were dehydrated in progressively more concentrated ethanol solutions, critical point dried, and coated with gold alloy for the scanning electron micrographs using a Philips XL30 ESEM LaB6 Electron Microscope. The length of each larva was measured on the electron micrographs from the base of appendage I, the chelicerae, to the posterior end of the animal. Appendages expressed during larval development are: appendage I (chelicera), appendage II (palp), appendage III (oviger of adult male), appendage IV (first walking leg), appendage V (second walking leg) and appendage VI (third walking leg).

Walking legs begin their development as buds. A bud of a walking leg on the developing pycnogonid larva may take one of two distinct forms. Buds of the walking legs on the typical protonymphon have three articles or pseudosegments which are not delineated by arthrodial membranes. The terminal pseudo-segment has a spine at the tip and a single spine on the second article. The walking leg buds of encysted larva and attaching larva taper smoothly to their distal end, and lack the pseudo-segments seen in the developing larva of the typical protonymphon (Nakamura, 1981; Bane, 2003; Brenneis et al, 2011).

The following labels are used in the electron micrographs: I — chelicera; II — second larval appendages or palps; III — third larval appendages or ovigers; $\mathrm{Pb}$ - proboscis; TM - tripartite mouth; IV — first walking legs; V — Second walking legs; VI — third walking legs; 1 6 segments of the first walking leg in the third instar.

\section{Results}

The protonymphon or first instar, second and third instars of $A$. allopodes is described from the electron micrographs. The Protonym- 


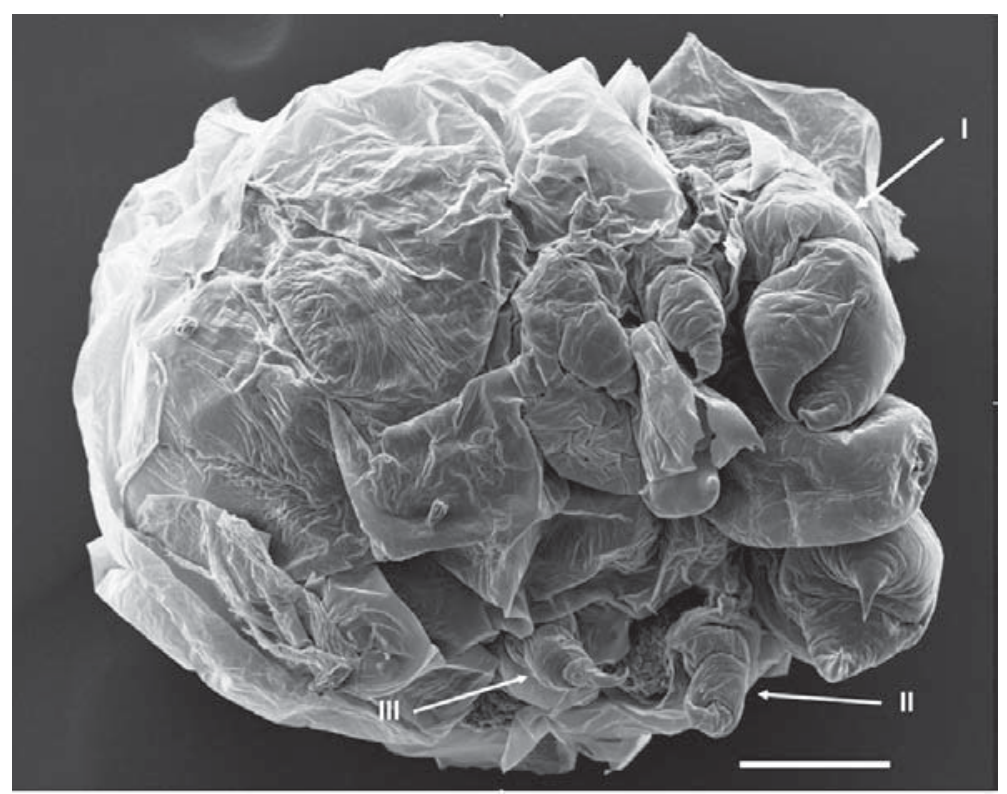

Fig. 1. Electron micrograph of the protonymphon larva of $A$. allopodes. The scale bar is $100 \mu \mathrm{m}$. Рис. 1. Протонимфон A. allopodes. Масштаб 100 мкм.

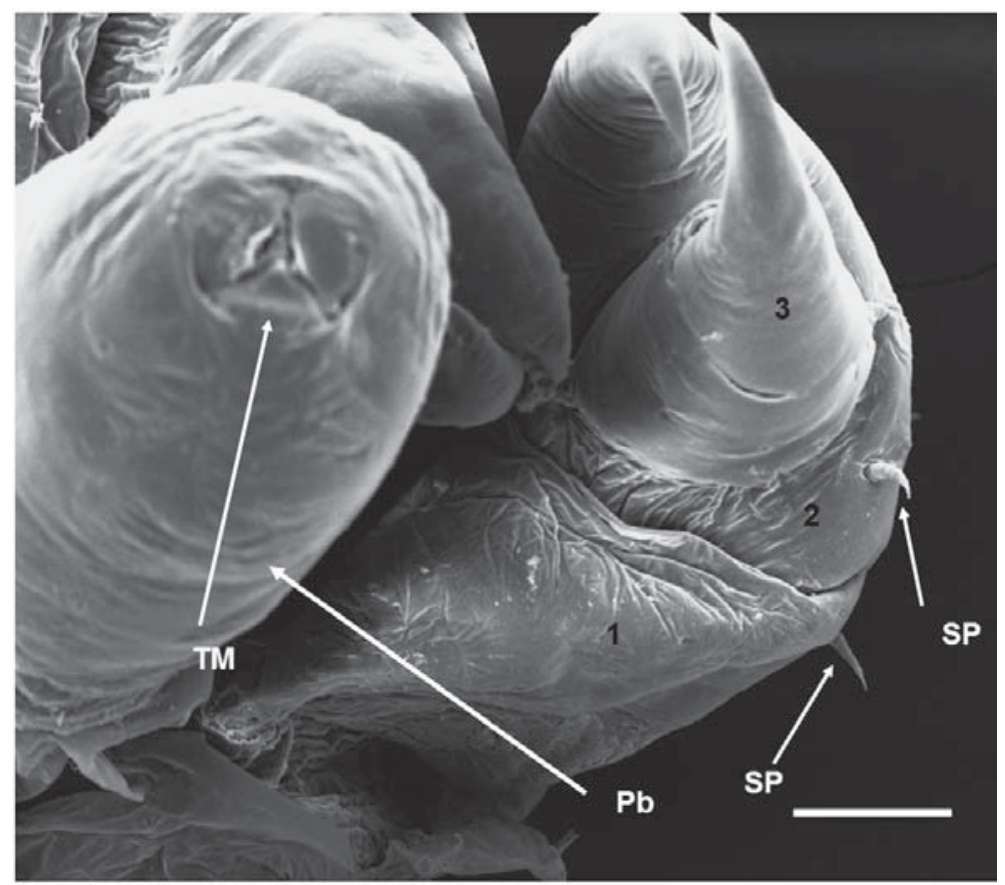

Fig. 2. The cheliphores of the protonymphon larva A. allopodes. The scale bar is $50 \mu \mathrm{m}$. Рис. 2. Хелифоры протонимфона A. allopodes. Масштаб 50 мкм.

phon is $440 \mu \mathrm{m}$ long $\mathrm{X} 440 \mu \mathrm{m}$ wide. Proboscis is shorter than the 3 -segmented chelicera. Larval appendages II and III also are 3-segmented.
Chelicera, appendage I, have a short, stout spine on the first and second segments. Buds of first walking leg, tubercle or proctodeum were not 


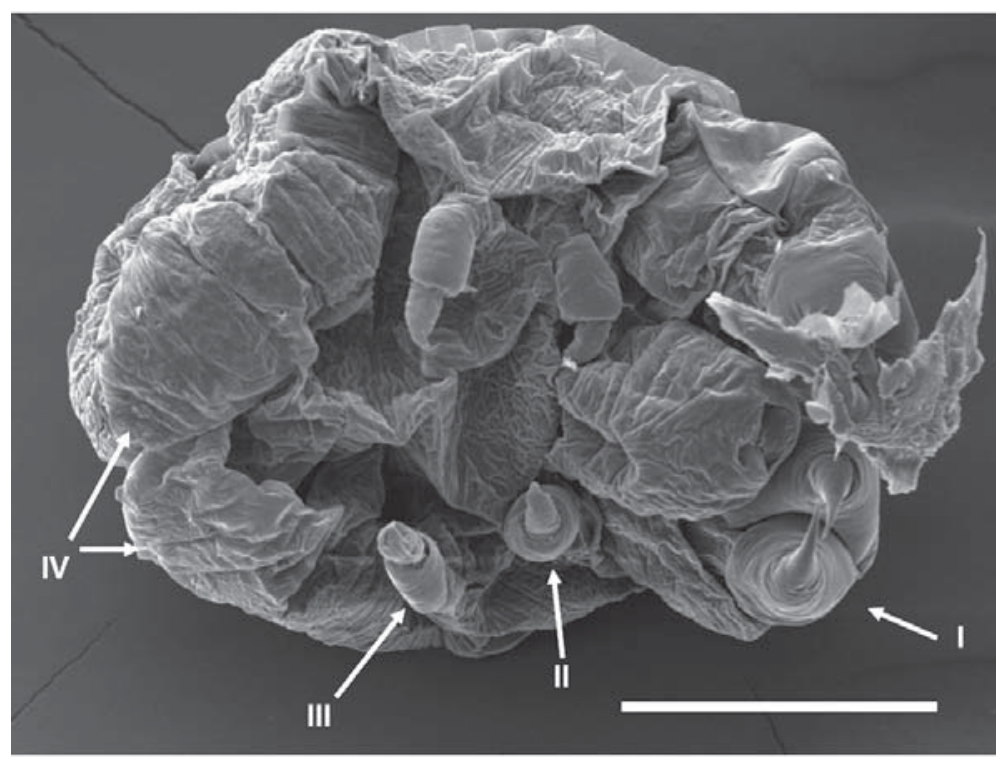

Fig. 3. The second instar of $A$. allopodes. The scale bar is $100 \mu \mathrm{m}$.

Рис. 3. Личинка второго возраста A. allopodes. Масштаб 100 мкм.

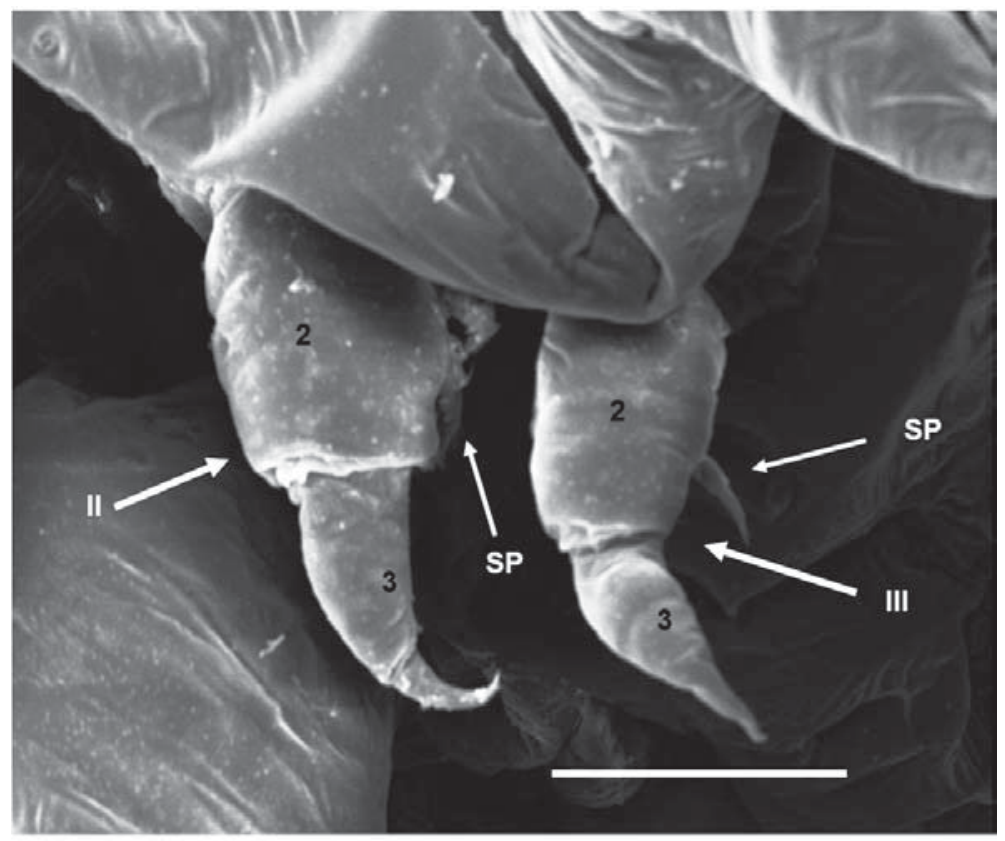

Fig. 4. Larval appendages II and III of a second instar larva of $A$. allopodes. The scale bar is $50 \mu \mathrm{m}$. Рис. 4. Личиночные конечности II и III личинки второго возраста A. allopodes. Масштаб 50 мкм.

observed (Figs. 1 and 2). Second Instar: $440 \mu \mathrm{m}$ long X $320 \mu \mathrm{m}$ wide. Proboscis with tripartite mouth structure is as long as the chelicera. Appendages II and III are 3-segmented with a short spine on the second segment. Appendage IV is present as an underived bud with three articles and a spine on the second article. The third article ends as a spine (Figs. 3, 4 and 5). 


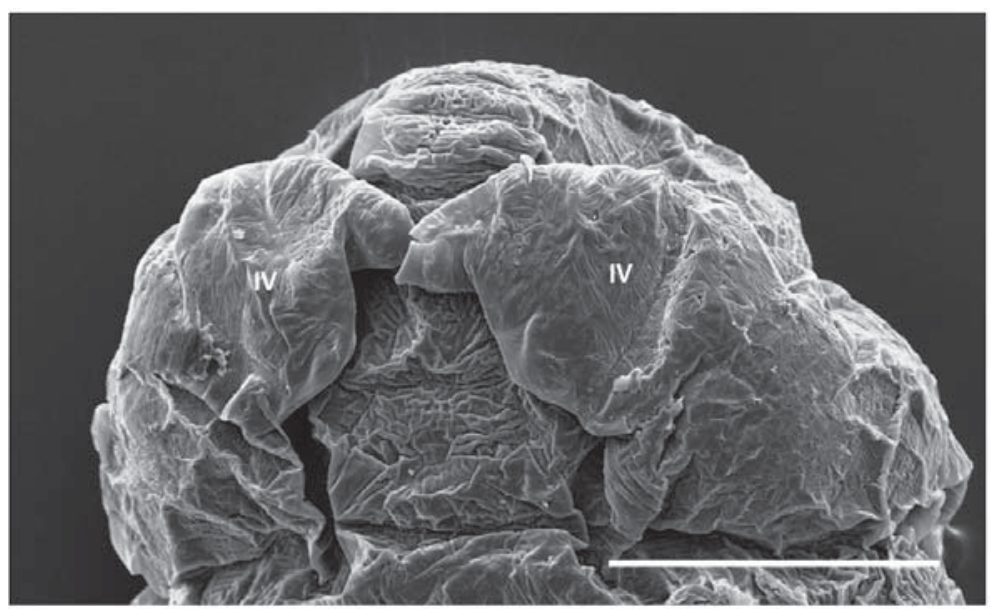

Fig. 5. The buds of the first walking legs of a second instar larva of $A$. allopodes. The scale bar is $100 \mu \mathrm{m}$. Рис. 5. Зачатки первых ходильных ног личинки второго возраста A. allopodes. Масштаб 100 мкм.

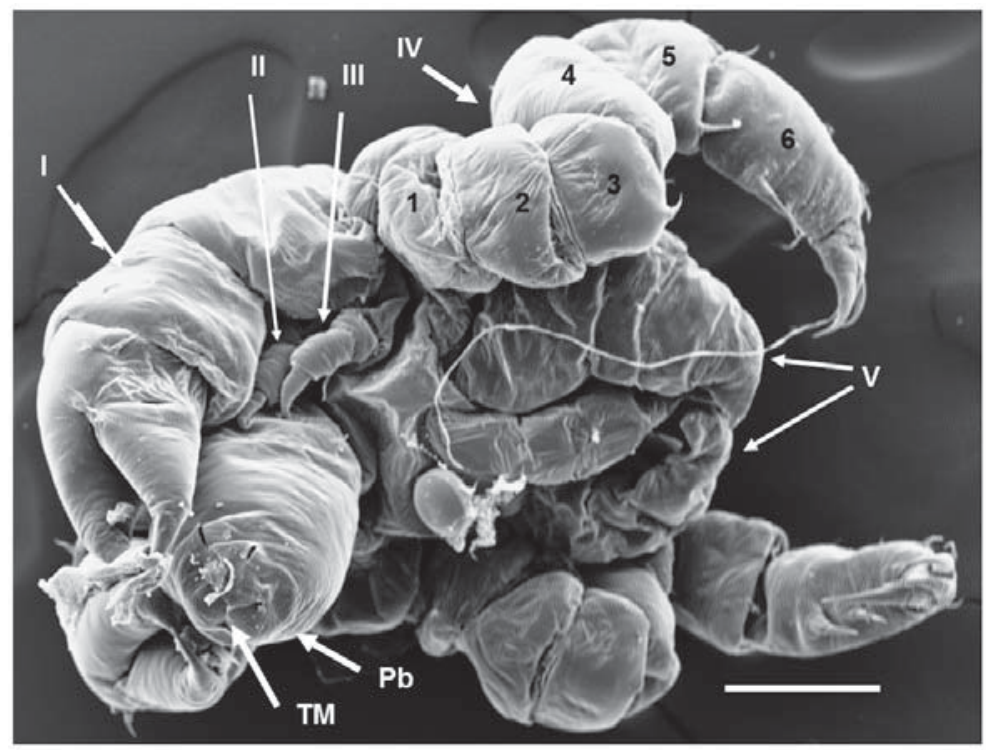

Fig. 6. The third instar larva of $A$. allopodes. The scale bar is $100 \mu \mathrm{m}$.

Рис. 6. Личинка третьего возраста A. allopodes. Масштаб 100 мкм.

Third instar: $353 \mu \mathrm{m}$ long X $230 \mu \mathrm{m}$ wide. The proboscis is longer than the cheliphores. Larval appendages II and III are the same as in second instar. Appendage IV has six segments. Appendage $\mathrm{V}$ present as an underived bud with three articles (Figs. 6 and 7).

A single larval stage of $N$. tenellum was found. The larva is $714 \mu \mathrm{m}$ long and $420 \mu \mathrm{m}$ wide. The anterior portion of the larva is less than half as wide as the posterior portion. The proboscis is about half of the length of the chelicera which are three segmented and lack a spinning gland spine (Fig. 8). Appendages II and III also are 3-segmented. There are three underived buds of appendages IV-VI, that lack arthrodial membranes. These buds taper smoothly to their distal end, and are not articulated like those of the second instar of $A$. allopodes. They decrease in length from appendage IV to appendage VI. Appendage IV has a spine mid-way 


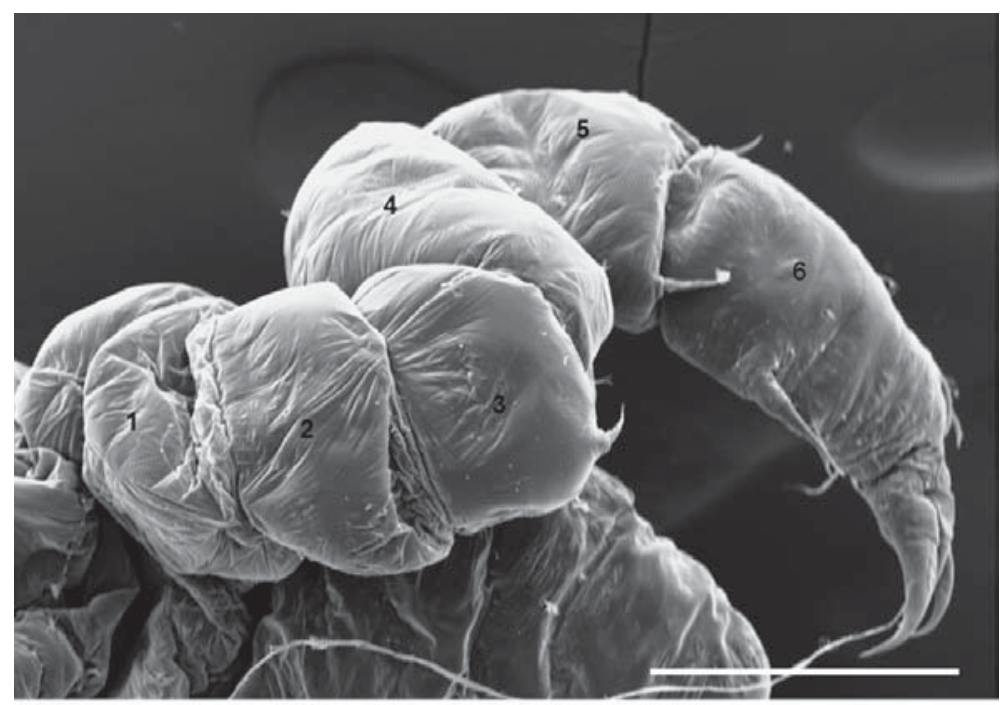

Fig. 7. The first walking leg of a third instar larva of $A$. allopodes. The scale bar is $100 \mu \mathrm{m}$.

Рис. 7. Первая ходильная нога личинки третьего возраста A. allopodes. Масштаб 100 мкм.

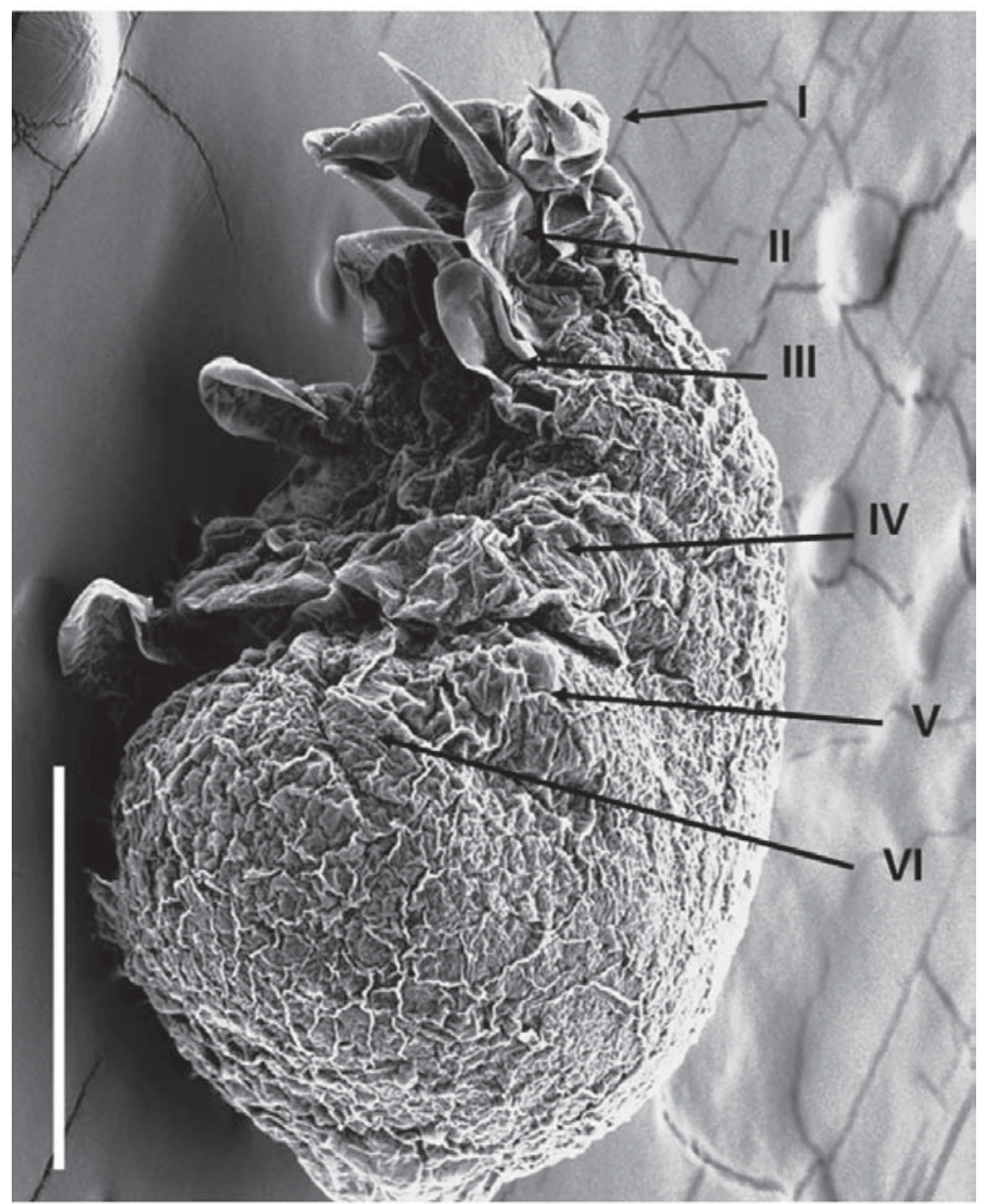




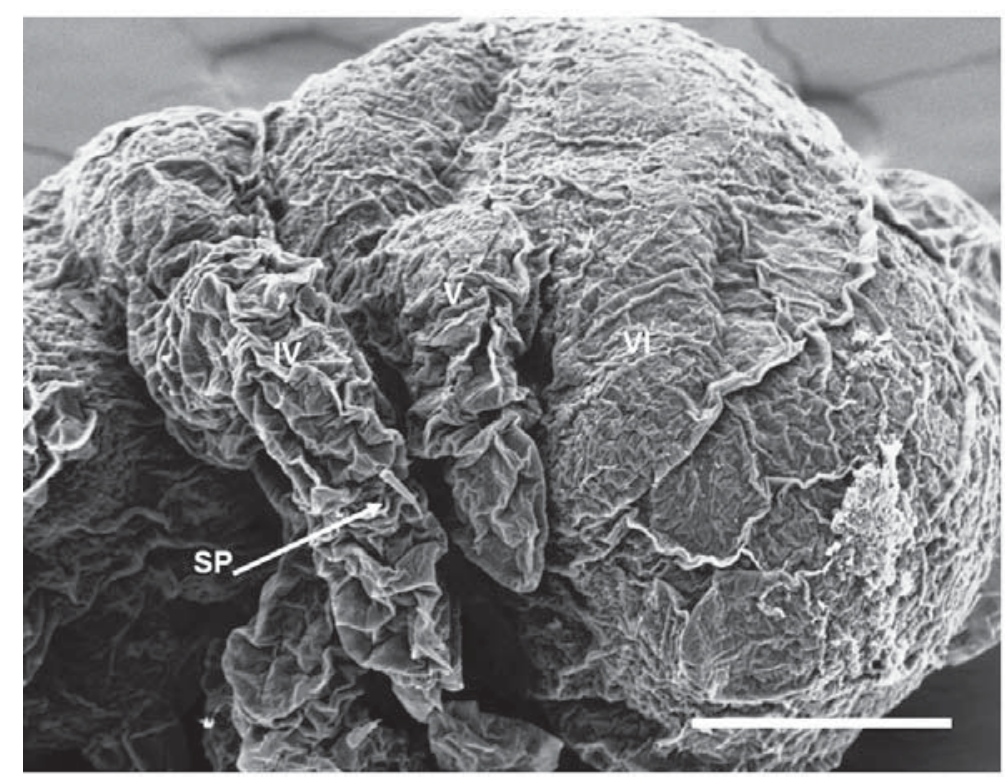

Fig. 9. Walking leg buds IV, V and VI of the post protonymphon larva of $N$. tenellum. The scale bar is $100 \mu \mathrm{m}$. Рис. 9. Зачатки ходильных ног IV, V and VI поздней личиночной стадии N. tenellum. Масштаб 100 мкм.

along its length. Appendages V and VI do not appear to have spines. The larva does not have a tubercle or an eye spot. There is no indication of an anus or proctodeum (Fig. 9).

\section{Discussion}

There are five distinct developmental patterns of post embryonic or larval development known to occur in the Pycnogonida, four proposed by Bain (2003) and one by Bogomolova and Malakhov (2006). These five developmental patterns are: typical protonymphon, which hatches from an egg with the anterior three pairs of 3-segmented appendages. As development proceeds, one pair of walking legs beginning with appendage IV is added at each molt, appearing first as an underived buds with three articles not separated by arthrodial membranes. The chelicera develop into the chelicera of the adults. The second pair of larval appendages are transformed into the palps of those species that have this appendage and the third pair of larval appendages become the ovigerous limbs in males. Atypical protonymphon, the second developmental pattern, the walking leg buds, appendages IV-VII are present at the first post protonymphon larval stage along with appendages I-III. These walking leg buds taper smoothly to their distal end, and lack pseudo-segments. Upon hatching, the morphology of an encysting larva is similar to the typical protonymphon, but soon after hatching appendages II and III fails to develop. During the third molt, appendages IVVI, which taper smoothly to their distal end, and lack pseudo-segments are added simultaneously, and appendage VII is added later. This pattern is seen in Phoxichilidium tubulariae Labour, 1945 by (Lovely, 2005). A fourth developmental pattern, the attaching larva, hatches without appendages II and III, but with smoothly tapered walking leg buds, lacking any pseudo-segments, of appendages IV and V. In the lecithotrophic protonymphon, the fifth developmental pattern, a protonymphon is the first postembryonic stage; this stage is large (about

Fig. 8. A post protonymphon larval stage of $N$. tenellum. The scale bar is $200 \mu \mathrm{m}$.

Рис. 8. Поздняя личиночная стадия $N$. tenellum. Масштаб 200 мкм. 
$0.5 \mathrm{~mm}$ in length) and has a store of yolk. Development of body segments and walking legs is strictly sequential. In addition, this larva differs from Bain's typical protonymphon larva in having a shortened spinneret spine, welldeveloped silk glands, and appendages II and III relatively short with a terminal segment which is not as well developed as in the typical protonymphon larva (Bain, 2003; Bogomolova, Malakhov, 2006). A protonymphon is the first stage of the typical, the atypical, the encysting and the lecithotrophic developmental patterns. It is characterized by an unsegmented body, a tripartite mouth at the end of a proboscis, and appendages I-III developed. Appendage I, the chelicera, remains 3-segmented throughout development. Appendages II and III, which in some pycnogonids degenerate in the post protonymphon larva are used for walking or, more rarely, swimming by the larva (Hoek, 1881; Morgan, 1891; Hodgson, 1907; Cano, LópezGonzález, 2009; Fornshell, 2014) Ammothea allopodes is an example of the typical protonymphon larva using Bain's (2003) classification scheme. It lacks the spinning gland and the associated spine on the first segment of the chelicera. The small spine on this segment may be homologous to the associated spine. Similar larvae for the genus Ammothea, A. carolinensis, A. clausi, A. minor, bicorniculata and A. longispina have been described from the Antarctic Ocean (Cano, López-González, 2009, 2013; Fornshell, Ferrari, 2012).

The encysting larva of the family Callipallenidae, in the genera Callipallene sp. and Neopallene sp. hatch as a protonymphon, but encyst in the body cavity of a coelenterate where it molts into a larval stage with appendage I, cheliphora, a rudiment of appendage II or III and the underived buds of appendages IV-VI (Brenneis et al., 2011).

The attaching larva of family Callipallenidae, Propallene longiceps (Böhm, 1879) described by Nakamura (1981) lack appendages II and III; underived buds of appendages IV and V present at hatching. Nakamura (1981) believed that the first molt occurred at or just before hatching. Pseudopallene spinipes which hatch- es as a post protonymphon larva with chelicera, a very small rudiment of larval appendage III and buds of the first two walking legs was described by Bogomolova and Malakhov (2004).

The difference in size between the egg and larva of $N$. tenellum suggests that the larval stage reported here are a later stage in the developmental sequence and not the hatching stage. It is characterized by the following: (1) appendages I-III are three segmented; (2) underived buds of appendages IV-VI similar to those seen on encysting larva and atypical larva; (3) an incomplete digestive tract as indicated by the absence of an anus; and (4) a large amount of yolk. The larva of $N$. tenellum described here displays some characteristics of an encysting larva in having appendages IV-VI present as underived buds but differs in having fully developed appendages II and III. The larva described here differs from an attaching larva in having the three anterior limbs fully developed, not just the first, and the underived buds of appendages IVVI present, not just appendages IV and V. Because this larva clearly does not match any of the larvae among the five developmental patterns proposed by Bain (2003) and Bogomolova and Malakhov (2006), a sixth larval type is proposed here to be called Elvie's larva, after Ms Elvie T. Fornshell. The complete description of the developmental pattern to which this larval stage belongs will have to await further collection of data.

\section{ACKNOWLEDGEMENTS}

I would like to thank Mr. Scott Whittaker for assistance with the operation of the electron microscope. Also I would like to thank my wife Elvie T. Fornshell for assistance in the production of the figures for this publication.

\section{References}

Bain B.A. 2003. Larval types and a summary of postembryonic development within the Pycnogonida // Invertebrate Reproduction and Development. Vol.43. No.3. P.193-222.

Brenneis G., Arango C.P., Scholtz G. 2011. Morphogenesis of Pseudopallene sp. (Pycnogonida, Callipallenidae) II: postembryonic development // Development Genes Evolution. Vol.221. P.329-350. 
Bogomolova E.V., Malakhov V.V. 2004. Fine morphology of larvae of sea spiders (Arthropoda: Pycnogonida) from the White Sea // Invertebrate Zoology. Vol.1. No.1. P. 3-28.

Bogomolova E.V., Malakhov V.V. 2006. [Lecithotrophic protonymphon is a special type of postembryonic development of sea spiders (Arthropoda, Pycnogonida)]// Doklady Akademii Nauk. Vol.409. No.4. P.328331 [in Russian, with English summary].

Cano E., López-González P.J. 2009. Novel mode of postembryonic development in Ammothea genus (Pycnogonida, Ammotheidae) from Antarctic waters // Scientia Marina. Vol.73. No.3. P.541-550.

Cano E., López-González P.J. 2013. New data concerning postembryonic development in Antarctic Ammothea species (Pycnogonida: Ammotheidae) // Polar Biology. Vol.36. No.8. P.1175-1193.

Fornshell J.A., Ferrari F.D. 2012. Larvae of the pycnogonids Ammothea gigantea Gordon, 1932 and Achelia cuneatis Child, 1999 described from archived specimens // Arthropods. Vol.1. No.4. P.121-128.
Hodgson T.V. 1907. Pycnogonida // National Antarctic Expedition 1901-1904. Vol.3. P.1-72.

Hoek P.P.C. 1881 Report on the Pycnogonida, dredged by H.M.S. Challenger during the years 1873-76// The Voyage of the H.M.S. Challenger Zoology. P.1-167. King P.E. 1973. Pycnogonids. London: Hutchinson \& Co. Ltd.

Lovely E.C. 2005 The life history of Phoxichilidium, tubulariae (Pycnogonida: Phoxilidiidae) // Northeastern Naturalist. Vol.12. No.1. P.77-92.

Morgan T.H. 1891. A contribution to the embryology and phylogeny of the Pycnogonids // Baltimore Press of Isaac Friedenwald, reprinted from: Studies from the biological laboratory of the Johns Hopkins University. Vol.5. No.1. P.1-76.

Nakamura K. 1981. Postembryonic Development of a Pycnogonid, Propallene longiceps // Journal of Natural History. Vol.15. P.49-62.

Responsible editors F.D. Ferrari, K.G. Mikhailov 